\title{
Technology Backstopping by Krishi Vigyan Kendra - A Boom for Escalating Income of Mango Growers in the District of Ramanagara, Karnataka, India
}

\author{
G. Keshavareddy ${ }^{*}$, K.H. Nagaraj ${ }^{2}$, B.G. Hanumantharaya ${ }^{3}$ and R. Narayana Reddy ${ }^{4}$ \\ ${ }^{1}$ Department of Entomology, ${ }^{2}$ Department of Extension, ${ }^{3}$ Department of Horticulture, \\ University of Agricultural Sciences, GKVK, Bengaluru-560065, Karnataka, India \\ ${ }^{4}$ Staff Training Unit, Hebbal, Bengaluru-560065, Karnataka, India \\ *Corresponding author
}

\section{Keywords \\ KVK, Mango, \\ Demonstration, \\ FLD, and Direct marketing}

\section{Article Info}

Accepted:

20 April 2018

Available Online:

10 May 2018

\section{A B S T R A C T}

Improved cultivation practices in mango from flowering to harvesting and marketing were demonstrated by Krishi Vigyan Kendra (KVK), Ramanagara through Frontline Demonstrations (FLDs) in the selected mango growers orchards from 2012-13 to 2017-18. The results of the demonstrations on pest management indicated the reduction in mean number of leaf hoppers infestation per panicle (0.77), fruits damage by fruit flies $(3.67 \%)$ and low incidence of powdery mildew (score 1.1) compared to farmers practice (score 2.74) plots. These three parameters are known to impact mainly the mango yield. The average tonnage increase in mango fruit yield per hectare in demo plots was 3.14 (48.31\%) over farmers practice. The huge variation in the per cent increase in yield was due to adoption of integrated crop management practices by the growers as demonstrated by the KVK. Adoption of improved technologies by the growers resulted in higher net returns of Rs. 235033 / ha as against the farmers practice (Rs. 140500/ha). KVK adopted cognizance approaches like group discussion meetings, extension literature distribution, news coverage about integrated crop management practices in mango to create awareness and knowledge of mango growers about various improved technologies. Realizing the importance, KVK took initiative with few interested mango growers and motivated them to take up scientific method of harvesting fruits, safe ripening and direct marketing of the produce to the consumers. The income obtained by the growers from direct marketing over on-farm contract increased by $356 \%$. There was horizontal spread of the safe ripening technology and direct marketing concept across the district through farmers who participated in the FLD. The demonstrated technologies proved to be highly remunerative compared to the existing farmers practice and on-farm contract for mango growers of the district 


\section{Introduction}

Mango is called the king of fruits owing to its attractive colour, flavor and taste apart from rich source of vitamins, minerals, fiber and antioxidants. Mango fruit is utilized at all stages of its development both in its immature and mature state. Raw fruits are used for making chutney, pickles and juices. The ripe fruits besides being used for desert, are also utilized for preparing several products like squashes, syrups, nectar, jams and jellies. The mango kernel also contains 8-10 per cent of good quality fat which can be used for soap and also as a substitute for cola in confectionery. In India, Mango occupies $21 \%$ of the total area under fruits comprising of 2.29 million hectares, with a total production of 15.18 million tons (Indian Horticulture Database, 2011). Uttar Pradesh and Andhra Pradesh, Telangana are having the largest area under mango each with around $25 \%$ of the total area followed by Bihar, Karnataka, Kerala and Tamil Nadu. India's share in the world mango market is about 15 percent. Mango accounts for 40 percent of the total fruit exports from the country. There is a good scope for increasing the area and productivity of mango in the country. Karnataka is the third largest mango producing state in India comprising 1.62 lakh ha with total production of 17.78 lakh tons. Kolar, Chikkaballapur and Ramanagara Districts are major mango growing areas in Karnataka. The Ramanagara district occupies second place in terms of area under mango (23000 ha) but the average yield per hectare is very low $(3.11 \mathrm{t} / \mathrm{ha})$. The major mango area (more than 90\%) in the district is under Alphonso variety which is having very good demand at local markets and as well as international level. Major hindrances for low productivity in the district are insect pests and disease damage. The other reasons for low yield are lack of knowledge among mango growers about maintenance of orchards with respect to nutrient management, tree pruning to remove excess and unproductive branches during July-August months and integrated pest and diseases management approaches for control of insect pests and diseases.

The major insect pests on mango in the district are leaf hoppers, stem borer and fruit flies while powdery mildew and anthracnose are the major yield reducing diseases. Insect pests and diseases together cause nearly $80 \%$ of crop loss and sometimes even much more according to grower's perception. Mango growers are also getting low income per unit area since farmers are underprivileged owing to lack of processing units and proper marketing facilities in the district for fresh mango fruits. As a result mango growers are forced to live in the clutches of the middlemen and the merchants. Many farmers were forced to sell the crop through on-farm contract for 23 years on a single contract. In addition to this, mango trees are becoming unproductive year after year due to poor maintenance of orchard with respect to nutrients management and indiscriminate spraying of inappropriate chemicals that deteriorates the tree health apart from developing resistance to insects. Considering all these problems faced by mango growers in the district, KVK intervened with suitable technology backstopping since 2012-13 educating farmers through FLDs on integrated pest and diseases management in mango from flowering to marketing. In the background, an attempt is made to analyze the various technologies demonstrated by the KVK that had an impact on yield and income of mango growers as well to understand the extension activities initiated by the KVK that put together contributed for escalating the income of the mango growers.

\section{Materials and Methods}

Krishi Vigyan Kendra is playing vital role in transfer of improved technologies to the farmers in general and in particular the mango 
growers. KVK, Ramanagara, conducted FLD's through Technology back stopping for mango growers from flowering to marketing every year in selected 10 mango grower's orchards of the district since 2012-13. However, three years data from 2013-14 to 2015-16 was considered for the study to analyze the technologies demonstrated by the KVK that had impact on yield and income of mango growers in 30 farmers orchard. The mango orchards of uniform age (11-12 years old) were selected at different villages on cluster village concept to demonstrate the technologies. To create awareness among the mango growers and to upscale their knowledge, KVK conducted capacity building programmes (On and Off campus training programmes), workshops, Mango melas in collaboration with line Departments viz., Karnataka State Department of Horticulture, Marketing Board and Karnataka Mango Development Board. As part of Front Line Demonstrations, technology back stopping w.r.t. various technologies like integrated pest management practices, pruning of excess and unproductive over crowed branches during June-July months, application of recommended fertilizers $(700 \mathrm{~g}$ N: $180 \mathrm{~g}$ P: $750 \mathrm{~g} \mathrm{~K}$ per tree of 10 years old and above aged plant) after pruning activity were method demonstrated. Preparation and spraying of mango special, a micro nutrients combination developed by Indian Institute of Horticulture Research (IIHR), Bengaluru was demonstrated by spraying at least for 3 times during crop period. Spraying of Alpha-Naphthalene Acetic Acid (NAA) @ 0.2ml per liter at flowering and after fruit set (when fruits are at marble size) were also method demonstrated in the demo orchards.

To manage insect pests particularly leaf hoppers, spraying with Imidachloprid $17.8 \%$ SL@0.5ml per liter and Lambda Cyhalothrin 5\% EC@0.5 ml per liter at 20 days interval ie. at inflorescence bud formation stage and immediately after fruit set was method demonstrated. To control powdery mildew disease, spraying with Hexaconazole 5\% SC @ $2 \mathrm{ml}$ per liter at flowering stage was method demonstrated. Other technologies like basal trunk cleaning and pasting with combination of Copper Oxychloride (40g) + Chlorpyrifos $(10 \mathrm{ml})+$ white distemper $(100 \mathrm{~g})$ in 1liter water to control mango stem borer infestation, soil raking under the mango trees and erecting 4-5 Methyl eugenol traps per acre were also demonstrated for management of fruit flies. Based on trap catches, famers were advised to take up chemical control of fruit flies Bactrocera dorsalis by spraying with Deltamethrin 2.8 EC @ 1ml per liter. The data on reduction in pest infestation and diseases incidence was recorded. The data on powdery mildew incidence was recorded by visual observations on the basis of area of young leaves and inflorescence affected by the disease. For this a self-designed disease scoring scale $0-5$ was used. Where $0=$ no disease incidence, $1=1-5 \%, 2=6-10 \%, 3=$ $11-25 \%, 4=26-50 \%$ and $5=51-100 \%$ disease incidence. Similarly fruit drop at marble size, fruit yield parameters were carefully recorded. Each parameter was expressed in per cent change over check. Here check is farmers practice. The per cent increase in yield is calculated by using the following formulae

Fruit yield under demo plot Fruit yield under farmer's practice Per cent increase in yield = ------------- X 100 Fruit yield under farmer's practice

As part of innovative approach, every year 10 mango growers were selected in the district. The innovative technologies were demonstrated with all 10 selected farmers like scientific harvesting of mangoes using fruit harvester by leaving 1 inch stalk on fruit, safe ripening of mangoes by using ethylene. For each cubic meter area of mangoes to be ripened, $2 \mathrm{ml}$ ethylene $+0.5 \mathrm{~g}$ caustic soda in 
plastic glass with $10 \mathrm{ml}$ water was kept for 24 hrs in air tight chamber. Next day, the air tight chamber was opened for better aeration. The fruits were ripened within 3-4 days after treatment with uniform colour development. The ripened fruits were graded and packed in $3 \mathrm{~kg}$ capacity designed cardboard boxes branded as "RAM GOLD". This brand was developed in collaboration with Department of Agricultural Marketing and Cooperation and Agri-Business Management, University of Agricultural Science, Bengaluru. The farmers were motivated to sell their mangoes under the brand name of RAM GOLD directly to the consumers at mango melas organized by Department of Horticulture, Zilla Panchayath, Ramanagara District, mango mela at Lalbagh and many other common places and nearby apartments in Bengaluru. Later the net income earned by the farmers by direct marketing over contract farming and mango sale at APMC (Agriculture Produce Market Committee) was compared and expressed in per cent increase.

\section{Results and Discussion}

The data on various parameters in mango after implementation of Front Line Demonstrations (FLDs) conducted from 2013-14 to 2015-16 are presented in the Tables 1,2 and 3. The pooled results of FLDs are presented in Table 4. It was observed that many stem borer infested mango trees $(57.89 \%)$ were rejuvenated after the basal stem cleaning and removal of the larva and pasting with Copper Oxychloride + Chlorpyrifos + White distemper. The average number of leaf hoppers infestation per panicle was 0.77 in demo plots compared to farmers practice (check) plots (10.37). The lowest average leaf hoppers population in demo plots is due to integrated pest management (IPM) practices adopted by the farmers. One such practice is adoption of scientific method of pruning during July-August months to remove excess and unproductive branches to allow proper aeration and sunlight into the tree canopy. This is one of the cultural practice recommended to manage the mango leaf hoppers. Pruning of crowded branches also helps in reduced incidence of black banded disease in mango which usually appears on twigs and branches of mango. If the black banded disease is severe, the twigs and branches will slowly wilt and dry.

Low incidence of powdery mildew (average score 1.1) on 0-5 scale score basis was observed in demo plots whereas the average disease incidence score in farmers practice plots was 2.74 which indicates the severity of the disease. In demo plots, powdery mildew disease incidence reduced by $59.85 \%$ over farmers practice (check). These results are in corroboration with findings of Raheel et al., (2008) where spraying with Hexaconazole reduced $86.67 \%$ per cent powdery mildew disease over control. The average number of fruit set per panicle was high (2.07) in demo plots than in farmers practice (1.26).

The high average number of fruits set in demo plots was mainly because of effective management of leaf hoppers and powdery mildew by taking control measures timely during November and December months. The weather conditions during these months are very congenial for both hoppers multiplication and powdery mildew out break which coincides with inflorescence emergence and fruit setting in mango particularly in Ramanagara district. The fruit drop was very high $(39.64 \%)$ in farmers practice during second fortnight of January and first fortnight of February compared to demo plots $(25.14 \%)$ when fruits were at marble size. Generally dry spells occur during the months of January and February in Ramanagara district. During this period one can expect high per cent of fruit drop due to moisture stress and gradual increase in day temperature. 
Table.1 Impact of demonstrated technologies on yield and income of mango growers during 2013-14

\begin{tabular}{|l|c|c|c|}
\multicolumn{1}{|c|}{ Parameter } & Check & Demo & $\begin{array}{c}\text { \% change } \\
\text { over check }\end{array}$ \\
\hline $\begin{array}{l}\text { Trees rejuvenated after } \\
\text { treatment for stem borer (\%) }\end{array}$ & - & $\begin{array}{c}64.28 \%(18 \text { of } \\
28 \text { trees) }\end{array}$ & - \\
\hline *Mango leaf hoppers (No.s) & 13.1 & 0.8 & -93.89 \\
\hline *Powdery mildew (0-5 scale) & 2.3 & 1.1 & -52.17 \\
\hline *Fruit Set (average number of & 1.1 & 1.8 & 63.63 \\
\hline fruits per inflorescence & & & \\
\hline panicle) & 47.23 & 32.30 & -31.61 \\
\hline *Fruit drop (\%) & 13 & 4 & -69.23 \\
\hline Fruits damaged by fruit flies & & & \\
\hline (\%) & 6.1 & 8.9 & 45.90 \\
\hline Yield (tones/ha) & 46500 & 57500 & 23.65 \\
\hline Gross cost /ha & 152500 & 240300 & 57.57 \\
\hline Gross income/ ha & 106000 & 176800 & 66.79 \\
\hline Net income & 3.28 & 4.18 & \\
\hline B: C ratio & & & \\
\hline
\end{tabular}

* Average of 10 panicles observation

Table.2 Impact of demonstrated technologies on yield and income of mango growers during 2014-15

\begin{tabular}{|c|c|c|c|}
\hline Parameter & Check & Demo & $\begin{array}{l}\text { \% change } \\
\text { over check }\end{array}$ \\
\hline $\begin{array}{l}\text { Trees rejuvenated after } \\
\text { treatment for stem borer }(\%)\end{array}$ & - & $\begin{array}{c}55.56 \%(5 \text { of } 9 \\
\text { trees })\end{array}$ & - \\
\hline *Mango leaf hoppers (No.s) & 9.8 & 0.6 & -93.87 \\
\hline *Powdery mildew (0-5 scale) & 2.8 & 0.9 & -67.86 \\
\hline $\begin{array}{l}\text { *Fruit Set (average number of } \\
\text { fruits per inflorescence } \\
\text { panicle) }\end{array}$ & 1.3 & 2.1 & 61.53 \\
\hline *Fruit drop (\%) & 37.5 & 20.06 & -45.07 \\
\hline $\begin{array}{l}\text { Fruits damaged by fruit flies } \\
(\%)\end{array}$ & 15 & 4 & -73.34 \\
\hline Yield (tones/ha) & 6.5 & 10.2 & 56.92 \\
\hline Gross cost /ha & 54500 & 62500 & 14.68 \\
\hline Gross income/ ha & 214500 & 336600 & 56.92 \\
\hline Net income & 160000 & 274100 & 71.31 \\
\hline B: C ratio & 3.94 & 5.39 & \\
\hline
\end{tabular}

* Average of 10 panicles observation 
Table.3 Impact of demonstrated technologies on yield and income of mango growers during 2015-16

\begin{tabular}{|c|c|c|c|}
\hline Parameter & Check & Demo & $\%$ change \\
\hline $\begin{array}{l}\text { Trees rejuvenated after } \\
\text { treatment for stem borer }(\%)\end{array}$ & - & $\begin{array}{c}53.84 \% \\
\text { (7 of } 13 \text { trees) }\end{array}$ & - \\
\hline *Mango leaf hoppers (No.s) & 8.2 & 0.9 & -89.02 \\
\hline *Powdery mildew (0-5 scale) & 3.1 & 1.3 & -58.06 \\
\hline $\begin{array}{l}\text { *Fruit Set (Average number of } \\
\text { fruits per inflorescence } \\
\text { panicle) }\end{array}$ & 1.4 & 2.3 & 64.29 \\
\hline *Fruit drop (\%) & 34.2 & 22.5 & -34.21 \\
\hline $\begin{array}{l}\text { Fruits damaged by fruit flies } \\
(\%)\end{array}$ & 16 & 3 & -81.25 \\
\hline Yield (tones/ha) & 6.9 & 9.8 & 42.03 \\
\hline Gross cost /ha & 51500 & 59400 & 15.33 \\
\hline Gross income/ ha & 207000 & 313600 & 51.50 \\
\hline Net income & 155500 & 254200 & 63.47 \\
\hline B: C ratio & 4.02 & 5.28 & \\
\hline
\end{tabular}

Table.4 Pooled results of Impact of demonstrated technologies on yield and income of mango growers

\begin{tabular}{|l|c|c|c|}
\hline \multicolumn{1}{|c|}{ Parameter } & Check & Demo & \% change \\
\hline $\begin{array}{l}\text { Trees rejuvenated after } \\
\text { treatment for stem borer (\%) }\end{array}$ & - & $57.89 \%$ & - \\
\hline Mango leaf hoppers (No.s) & 10.37 & 0.77 & -92.57 \\
\hline $\begin{array}{l}\text { Powdery mildew (0-5 scale) } \\
\text { Fruit Set (Average number of } \\
\text { fruits per inflorescence } \\
\text { panicle) }\end{array}$ & 2.74 & 1.1 & -59.85 \\
\hline Fruit drop (\%) & 1.26 & 2.07 & 64.29 \\
\hline $\begin{array}{l}\text { Fruits damaged by fruit flies } \\
\text { (\%) }\end{array}$ & 14.67 & 3.67 & -74.98 \\
\hline Yield (tones/ha) & 6.5 & 9.64 & 48.31 \\
\hline Gross cost /ha & 50833 & 59800 & 17.64 \\
\hline Gross income/ ha & 191333 & 296833 & 55.14 \\
\hline Net income & 140500 & 235033 & 67.28 \\
\hline B: C ratio & 3.75 & 4.95 & \\
\hline
\end{tabular}


Table.5 Extension educational activities carried out by KVK for the mango growers in the district of Ramanagara from 2013-14 to 2017-18

\begin{tabular}{|c|c|c|c|}
\hline Sl. No & Activity & $\begin{array}{c}\text { No. of } \\
\text { Programmes }\end{array}$ & $\begin{array}{c}\text { No. of } \\
\text { growers }\end{array}$ \\
\hline 1 & On- campus training programmes & 12 & 412 \\
\hline 2 & Off-campus training programmes & 34 & 658 \\
\hline 3 & Scientists visit to farmers mango orchards & 138 & 479 \\
\hline 4 & Diagnostic visits to mango orchards & 27 & 57 \\
\hline 5 & Short Message Services & 42 & 3405 \\
\hline 6 & Cell phone calls & 738 calls & 738 \\
\hline 7 & $\begin{array}{l}\text { News coverage about Integrated Crop Management in } \\
\begin{array}{ll}\text { Mango: } & \text { i) TV programmes } \\
& \text { ii) Local news papers }\end{array}\end{array}$ & $\begin{array}{c}3 \\
23\end{array}$ & - \\
\hline 8 & Advisory service through WhatsApp (since 2014) & 437 & 437 \\
\hline 9 & Farmers personal visit to KVK for advisory services & 783 & 783 \\
\hline 10 & Through workshops & 7 & 419 \\
\hline 11 & Through mango melas & 12 & 811 \\
\hline 12 & Though collaborative programmes & 16 & 687 \\
\hline 13 & Through group discussions with mango farmers & 56 & 398 \\
\hline 14 & Field days & 3 & 95 \\
\hline 15 & $\begin{array}{l}\text { Extension literature } \\
\text { i) } \quad \text { Folders } \\
\text { ii) } \\
\text { Leaf lets }\end{array}$ & $\begin{array}{l}250 \\
500\end{array}$ & $\begin{array}{l}250 \\
500\end{array}$ \\
\hline 16 & Method demonstrations & 65 & 910 \\
\hline \multicolumn{3}{|c|}{ Total } & 11039 \\
\hline
\end{tabular}

Table.6 Cases of impact of direct marketing on income of trained mango growers as part of innovative approach adopted by KVK

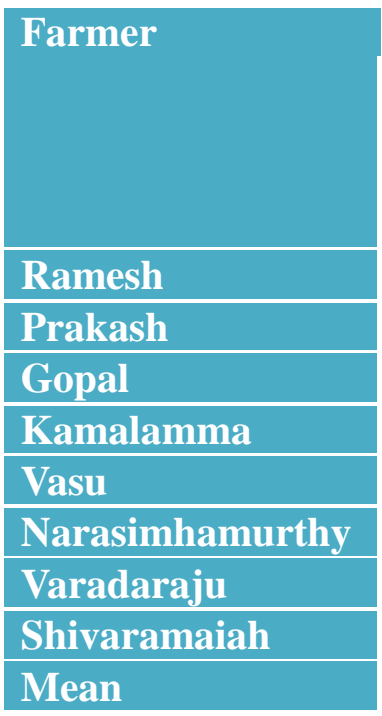

\begin{tabular}{|c|c|c|c|c|c|}
\hline \multirow{2}{*}{$\begin{array}{l}\text { Total } \\
\text { Yield } \\
\text { (t/ha) }\end{array}$} & \multicolumn{3}{|c|}{ Income (Rs.) } & \multirow[b]{2}{*}{$\begin{array}{l}\text { Additional } \\
\text { income from } \\
\text { APMC market } \\
\text { over on farm } \\
\text { contract }(\%)\end{array}$} & \multirow[b]{2}{*}{$\begin{array}{l}\text { Income from } \\
\text { direct } \\
\text { marketing over } \\
\text { on farm } \\
\text { contract }(\%)\end{array}$} \\
\hline & $\begin{array}{l}\text { On farm } \\
\text { Contact }\end{array}$ & $\begin{array}{l}\text { Sale at } \\
\text { APMC }\end{array}$ & $\begin{array}{l}\text { Direct } \\
\text { Marketing }\end{array}$ & & \\
\hline 10.07 & 125000 & 265625 & 650000 & 112.50 & 420.00 \\
\hline 9.10 & 135000 & 225000 & 585000 & 66.66 & 333.33 \\
\hline 10.10 & 143000 & 250000 & 652000 & 74.82 & 356.40 \\
\hline 10.12 & 153500 & 249000 & 649000 & 62.21 & 323.26 \\
\hline 7.0 & 85000 & 175000 & 530000 & 105.88 & 523.52 \\
\hline 11.0 & 150000 & 275000 & 880000 & 83.33 & 486.66 \\
\hline 8.5 & 110000 & 212500 & 680000 & 93.18 & 518.18 \\
\hline 8.00 & 112000 & 200000 & 720000 & 78.57 & 542.85 \\
\hline 9.24 & 126687 & 231515 & 668250 & 84.64 & 438.03 \\
\hline
\end{tabular}


Spraying with NAA@0.2ml per liter of water in demo plots significantly reduced $(36.58 \%)$ the fruit drop compared to farmers practice. Fruits damaged by fruit flies in demo plots was very low $(3.67 \%)$ compared to farmers practice $(14.67 \%)$ which is very high. Damage caused by fruit flies is more than normal seasons when one or two unseasonal (Pre-monsoon) showers occurs during the months of March and April in the district (Farmers personal communication).

The average fruit fly damage $(3.67 \%)$ in demo plots is very low compared to farmers practice $(14.67 \%)$ is due to adoption of integrated pest management practices like soil raking up-to 10 $\mathrm{cm}$ depth under the trees to expose pupae of flies to natural enemies. Five to six Methyl eugenol traps were erected per acre during fruit maturation and harvesting stage and a spray was taken with Deltamethrin 2.8\% EC @ $1 \mathrm{ml}$ per liter of water along with $2-3 \mathrm{~g}$ jaggery when average trap catch of flies exceeds five numbers in a day in demo plots. This practice resulted in effective management of fruit flies in demo plots. The results of front line demonstrations clearly indicated that average fruits yield in demo plots $(9.35 \mathrm{t} / \mathrm{ha})$ is much more when compared to farmers practice $(6.5 \mathrm{t} / \mathrm{ha})$, which was mainly due to integrated crop management practices. Adoption of scientific package of practices like pruning and application of $700 \mathrm{~g}$ $\mathrm{N}: 180 \mathrm{~g}$ P: $750 \mathrm{~g} \mathrm{~K}$ per tree (10 years and above aged trees) during June-July months and need based right plant protection practices resulted in higher yields. Spraying with NAA when fruits were at marble size and 2 to 3 protective irrigations during the months of February March also significantly contributed to higher yields. This is attributed to reduced fruit drop in demo plots compared to framers practice.

Economic returns related to input and output prices of men and material prevailed during the study period was recorded. The mango cultivation by adopting improved technologies as demonstrated through FLD gave higher net returns Rs. 235033 per hectare as against farmers practice (Rs. 140500 per hectare, Table 4). Similar results were noticed by the findings of Raj et al., (2013) and Singh et al., (2014). The Benefit: Cost ratio of mango during all the three years, 2013-14. 2014-15 and 2015-16 (Table 1, 2 and 3) under improved cultivation practices were $4.18,5.39$ and 5.28 respectively while it was 3.28, 3.94 and 4.02 under farmers practice for the respective years. The higher net return in demo plots is attributed to higher yields per unit area. The cost of cultivation in demo plots was little higher compared to farmers practice plots (check plots) during all the three years. This is mainly attributed to extra cost of specific chemicals like NAA, cost of labour charges for spraying, for giving protective irrigations and harvesting higher yield in demo plots. However, the overall net returns were much higher (67.28\%) from demo plots compared to farmers practice plots.

\section{Technologies dissemination approaches to mango growers}

Krishi Vigyan Kendra bridges the gap between the various technologies developed at research institutions and State Agriculture and Horticulture Universities and their adoption at the field level by the mango growers through various approaches. The data from Table 5 indicates that, to create awareness about various technologies among mango growers KVK adopted cognizance approaches like group discussion meetings (56 no.s) were conducted covering 398 farmers. The other methods adopted were extension literature distribution (folders-250 and leaf lets -500) and news coverage (through 3 TV programmes-ETV Kannada Annadatha programmes and local news papers). As a tool of ICT, KVK has implemented Agriculture Short Message Services (ASMS). In five years period, totally 42 SMS regarding mango technologies were sent reaching 3405 farmers. Methodological approaches are the main stay of KVK to upscale technologies to the farmers. Front line demonstrations (50 no.s), On-campus and Offcampus training programmes (together 46 no.s) covering 1270 farmers and 3 field days reaching 95 farmers were conducted. Other cognizance approaches adopted by KVK to reach mango 
farmers are scientists visits to farmers orchards (138 visits), diagnostic visits (27), Advisory service through WhatsApp (437), scientists conducting/participating in line Departments collaborative programmes, mango workshops, mango melas etc. KVK Ramanagara is also preparing mango special and making it available to mango growers of the district at suitable times of requirements.

A great majority of mango growers in the district out-source the mango orchards to the traders for harvesting and sale of the crop. As an innovative approach, KVK interfered with few interested mango growers and motivated those to take up scientific method harvesting, ripening, grading and branding of the mangoes at farm level and sell the mangoes directly to the consumers under the brand name of "Ram Gold". This resulted in drastic increase in the income of farmers from Rs. 126687/ha/year to Rs. 668250 /ha/year (Table 6). With the horizontal spread of technology to the FLD participated and non-participated farmers, the income from direct marketing over on-farm contract increased by up to $542.85 \%$ and the additional income obtained from APMC market over on-farm contract varied from $62.21 \%$ to $112.5 \%$. Similar findings were reported by Shubha (2012). The cases of eight farmers who were involved in direct marketing and earning more income are depicted in Table 6. The results clearly indicated the effect of various technologies on mango production and its impact on escalating mango grower's income. Scaling takes time and adaptability. It requires a systems approach where in all the stakeholders should be actively involved. KVK and all the stake holders involved are required to up-scale the interventions in terms technologies considering vertical and horizontal spread. A well-defined value chain involving farmers and institutions is the need of the hour for upscaling the technologies. Further there is a need to build suitable conditions for enhanced crop productivity in the present climate change scenario (Reena, 2013). KVK, Ramanagara works in cluster village concept covering selected farmers. However, efforts would be augmented to involve all the stake holders and strive hard to double or escalate farmers income.

\section{References}

National Horticulture Board. 2011. Indian Horticulture Database. Pp.296.

Raheel, M., S. A. Anwar, N. Javed, M. B. Ilyas, M. Iqbal and Zia, A. 2008. Management of Powdery Mildew of Mango by Foliar Spray Fungicides. Pak. J. Phytopathol. 21(1): 173-174.

Raj, A. D., V. Yadav and Rathod, J. H. 2013. Impact of Front Line Demonstration on the yield of Pulses. Int. J. Sci. Res. Public. 3(9): 2250-2254.

Reena, K. 2013. Role of KVK's in the Climate Change Scenario. Indian Farming, 63(8): 3-6.

Shubha, R. 2012. Economic Analysis of Production and Marketing of Jaggery in Mandya District of Karnataka. Mysore J. Agric. Sci. 46(4):942

Singh, D., A. K. Patel., S. K. Baghel, M. S. Singh, A. Singh and Singh, A. K. 2014. Impact of Front Line Demonstration on the Yield and Economics of Chickpea in Sindhi District of Madhya Pradesh. J. Agril.Res. 1(1):22-25.

\section{How to cite this article:}

Keshavareddy, G., K.H. Nagaraj, B.G. Hanumantharaya and Narayana Reddy, R. 2018. Technology Backstopping by Krishi Vigyan Kendra - A Boom for Escalating Income of Mango Growers in the District of Ramanagara, Karnataka, India. Int.J.Curr.Microbiol.App.Sci. 7(05): 2751-2759. doi: https://doi.org/10.20546/ijcmas.2018.705.319 